УДК 633.15:631 / 527

(C) 2016

Харченко Ю. В., кандидат сільськогосподарських наук, Харченко Л. Я., науковий співробітник

Устимівська дослідна станція рослинництва

Клімова О. Є., кандидат сільськогосподарських наук

Синельниківська дослідна станція

\title{
БІОЛОГІЧНА І ГОСПОДАРСЬКА ОЦНКА НОВИХ ЗРАЗКІВ ЦУКРОВОЇ КУКУРУДЗИ НА УСТИМІВСЬКІЙ ДОСЛІДНІЙ СТАНЦІЇ РОСЛИННИЦТВА
}

\author{
Рецензент - кандидат сільськогосподарських наук О. В. Тригуб
}

3'ясовано потениіийні можливості інбредних ліній иукрової кукурудзи за продуктивністю і ї̈ складовими (кількість зерен на качані, кількість рядів зерен на качані, довжина качана, маса 1000 зерен) в умовах лісостепової зони Украӥни. Виявлено зразки з різним ступенем екологічної адаптації, щзо забезпечує виконання програм зі створення екологічно-орієнтованих гібридів. За результатами досліджень виділено изінні для практичної селекиії генотипи та запропоновано шляхи їх подальшого використання в гетерозисній селекиії даного підвиду кукурудзи.

Ключові слова: иукрова кукурудза, лінія, ознака, продуктивність, екологічна мінливість, селекиійна ичінність.

Постановка проблеми. У провідних країнах світу близько 20-35 \% валового збору зерна кукурудзи використовують на продовольчі потреби, а споживання на душу населення на рік сягає понад 28-32 кг. В Україні цей показник варіює від 2,5-3,5 кг у східних до 9-12 кг - у західних областях. Цукрова кукурудза $є$ цінною сировиною для виробництва різноманітних продуктів харчування, попит на які невпинно зростає. Її зерно містить вітаміни, органічні кислоти, целюлозу, пектинові сполуки, білки, жири і мінеральні речовини. Маючи високу поживну цінність, кукурудза володіє також дієтичними та лікувальними властивостями. Висока біологічна цінність товарної продукції обумовлена підвищеною якістю зерна за рахунок оптимального поєднання в ньому різних структурних вуглеводів (моно-, дицукриди, сахароза, декстрини та крохмаль). Багатоцільове використання (у свіжому, замороженому, висушеному та консервованому вигляді), здатність рости і плодоносити в різних кліматичних зонах створюють передумови для подальшого розширення виробництва товарної продукції цього підвиду кукурудзи $[1,2]$.

Аналіз основних досліджень і публікацій, у яких започатковано розв'язання проблеми.
У традиційній селекції цукрової кукурудзи використовується біохімічний ефект мутантного гену sugary-1 ( $\left.\mathrm{su}_{1}\right)$, який полягає у зниженні активності крохмаль-дерозгалужуючих ферментів і підвищенні вмісту в зерні водорозчинних фракцій вуглеводів [3-5]. Водночас у кукурудзи ідентифіковано й інші мутантні гени, ефект яких може бути результативно використано для поліпшення вуглеводного складу зерна. До них належать, зокрема, мутантні гени shrunken-1 $\left(\mathrm{sh}_{1}\right)$ та shrunken-2 $\left(\mathrm{sh}_{2}\right)$, які відповідно знижують активність цукрозо-синтази та АДФ-глюкозопірофосфорилази і підвищують вміст цукрози в технічно стиглому зерні [9-12]. Проте тільки високої якості товарної продукції ще не досить для забезпечення практичної цінності гібридів цукрової кукурудзи на основі цих мутацій. Вони повинні поєднувати високий вміст водорозчинних фракцій вуглеводів з високими рівнями інших господарчих ознак, насамперед зернової продуктивності, яка залежить не тільки від специфіки гібридної комбінації, але й від грунтовокліматичних умов зони вирощування [10]. Аналіз сучасного стану вирощування цукрової кукурудзи свідчить про те, що іiі сорти і гібриди не повністю відповідають вимогам виробництва i потребують подальшого підвищення врожайності і поліпшення інших морфо-біологічних ознак. А це можливе за наявності сучасного, високоякісного вихідного матеріалу.

Мета досліджень - оцінка ліній цукрової кукурудзи за комплексом ознак продуктивності та стабільністю їх прояву, які в сукупності відображають селекційну цінність генотипу (СЦГ), та виділення генотипів, найбільш придатних для практичного використання в гетерозисній селекції.

Завдання досліджень - виділити генотипи, найбільш придатні для практичного використання в гетерозисній селекції.

Матеріал, методики та умови досліджень. Вивчення адаптивних характеристик 31 лінії цук- 


\section{СІЛЬСЬКЕ ГОСПОДАРСТВО. РОСЛИННИЦТВО}

рової кукурудзи за рівнем ознак продуктивності та їх реакції на екологічні фактори проведено в 2010-2012 pp. Лінії цукрової кукурудзи були надані провідним науковим співробітником Інституту сільського господарства степової зони НААН О. Є. Клімовою. Дослідження проводили в польових умовах Устимівської дослідної станції рослинництва, в центральній частині лівобережної України, на межі між лісостеповою та степовою зонами. Попередник - чистий пар. Грунт - середньосуглинистий, малогумусний, розпилений чорнозем.

Під час проведення досліджень та оцінки ліній керувались відповідними методиками [6, 1] 3 урахуванням специфіки підвиду цукрової кукурудзи. Зразки висівалися на дворядковій ділянці площею $9,8 \mathrm{~m}^{2}$ із розташуванням рослин за схемою 70х70 см (2 рослини в гнізді). Протягом вегетаційного періоду проводили спостереження та опис ліній за класифікатором-довідником [3]. Зразки були оцінені за 18 господарсько-цінними ознаками.

Агротехніка - загальноприйнята для зони вирощування 3 урахуванням специфіки цукрової кукурудзи.

Метеорологічні умови років досліджень характеризувались широким спектром варіювань, що дало змогу проаналізувати інтродукований матеріал на адаптивність до умов Полтавської області. За вегетаційний період 2010-1012 років випало 285,5, 416,2 та 182,6 мм опадів за середнього багаторічного показника 299 мм, що становило 95,5, 139,2 та 65 \%. Водночас середньодобова температура становила $22,1,20,3$ та $24,1^{\circ} \mathrm{C}$, що вище на 22,1, 12,2, 28 \% від багаторічних даних $\left(18,1^{\circ} \mathrm{C}\right)$. Високі значення температури повітря в період росту i розвитку рослин у почасових $\mathrm{i}$ просторових екоградієнтах прискорювали проходження етапів морфогенезу кукурудзи і вона, призупиняючи вегетацію в II і III декаді серпня, практично не використовувала опади вересня. Для оцінки забезпечення рослин вологою використовується гідротермічний коефіцієнт (ГТК), котрий є показником, що враховує як надходження води у вигляді дощів у теплий період року, так і сумарної іï витрати на випаровування. Так, згідно з Г. Т. Селяніновою і С. А. Сапожніковою, величина ГТК понад 1,6 характеризує надмірне зволоження, 1-0,7 - посушлива зона, 0,7-0,4 дуже посушлива зона. Доведено, що найкращі умови для отримання значних урожаїв зернових культур у разі весняних строків посіву створюються, коли ГТК за відповідний період їх вегетації становить 1-1,4 [7]. Гідротермічний коефіцієнт (ГТК) за червень-серпень, у період інтенсивного росту рослин, формування качанів і наливу зерна в 2010 та 2012 роках, становив 0,6, тобто критичний період розвитку рослин співпадав 3 аномально-посушливими умовами, а в 2011 р. у випадку надмірного зволоження - ГТК $=1,84$.

Результати дослідження. Під час вивчення генетичної різноманітності 31 самозапиленої лінії кукурудзи основна увага в наших дослідах приділялась наступним показникам: тривалості вегетаційного періоду, продуктивності та іi складовим, стійкості до враження шкідниками та хворобами, стійкості до вилягання та ламкості стебла, стійкості до впливу стресових кліматичних чинників.

Тривалість вегетаційного періоду є основною ознакою, яка характеризує екологічний напрям використання вихідного матеріалу в гетерозисній селекції. Вона $є$ найбільш екологічно мінливою ознакою i обумовлена двома головними чинниками. 3 одного боку - це індивідуальні властивості (генотип) зразка, з іншого - умови, в яких він росте і розвивається (температура, вологість, родючість грунту та інше). Під час розподілу зразків по групах стиглості ми враховували такі показники, як кількість діб від появи сходів до повної стиглості зерна, кількість листків на рослині з урахуванням суми ефективних температур згідно 3 довідником «Оптимальні умови росту та розвитку рослин кукурудзи», сформованого в Інституті рослинництва ім. В. Я. Юр'єва [3]. За фенологічними спостереженнями та за кількістю листків на головному стеблі зразки розподілились на середньоранні (25\%), середні (69\%) та середньопізні (6\%). До середньоранніх віднесено лінії КЦ 502-1, ВН 1, КЦ 906-1, КЦ 705-1. Виділено лінії зі стабільно коротким по роках вивчення періодом «посів сходи»: КЦ 346-2-1, КЦ 906-1, РКЦ 12-1, РКЦ 36, РКЦ 910, КЦ 27-5, КЦ 42-3 - 12 діб.

Статистичною обробкою отриманих даних встановлено наявність різноманіття ліній за рівнем середніх, мінімальних і максимальних значень та ступенів мінливості ознак у межах аналізованих вибірок (табл. 1).

Результати групового аналізу мінливості морфо-біологічних ознак та господарських показників ліній дали можливість встановити їх різноякісність за оцінюваними параметрами (табл. 1), що підтверджено середніми та високими показниками коефіцієнтів варіації (11,1-36,3\%) для більшості ознак, за виключенням виходу зерна, тривалості вегетаційного періоду (V=7,9-10,3%).

Середня варіабельність встановлена для довжини та товщини качана, висоти рослини - в межах 11,1-15,9\%. 


\section{1. Різноякісність ознак морфоструктури ліній цукрової кукурудзи в умовах Устимівської дослідної станції рослинництва, 2010-2012 рр.}

\begin{tabular}{|c|c|c|c|c|}
\hline Ознака & середнє & $\min$ & $\max$ & $\mathrm{V}, \%$ \\
\hline Продуктивність зерна з рослини, г & 69,3 & 16,1 & 115 & 35,4 \\
\hline Довжина качана, см & 13,4 & 10,2 & 18 & 14,9 \\
\hline Кількість зерен у ряду, шт. & 27,2 & 14,6 & 40,1 & 21,3 \\
\hline Кількість рядів зерен, шт. & 14,5 & 10,5 & 19,2 & 16,3 \\
\hline Кількість зерен на качані, шт. & 219,3 & 100,9 & 484,5 & 36,3 \\
\hline Товщина качана, см & 4,0 & 2,5 & 5,1 & 11,1 \\
\hline Маса 1000 зерен, г & 231,1 & 112 & 320 & 19,7 \\
\hline Вихід зерна, \% & 79,4 & 58,7 & 88,0 & 7,9 \\
\hline Кількість качанів на рослині, шт. & 1,28 & 0,3 & 2 & 30,6 \\
\hline Висота рослини, см & 165,5 & 98 & 219 & 15,9 \\
\hline Висота прикріплення качанів, см & 40,7 & 21 & 81 & 32,6 \\
\hline Період «сходи - цвітіння качанів», діб & 55,3 & 40 & 70 & 10,3 \\
\hline Період «сходи - повна стиглість», діб & 105 & 77,8 & 124 & 8,1 \\
\hline
\end{tabular}

Показники мінімального та максимального прояву цих ознак засвідчують підвищене їх різноманіття.

Ознаки продуктивності рослини та їі складових елементів і висоти прикріплення качанів характеризувались більш високою мінливістю $\mathrm{V}=16,3-36,3 \%$.

Порогові мінімальні та максимальні значення цих ознак знаходились на значному віддаленні, що вказує на наявність значного різноманіття ліній за цими показниками. Висота рослини та висота прикріплення качанів характеризує придатність ліній до механізованого збирання.

Окрім того високорослі форми забезпечують вищу врожайність. Прояв цих ознак у цукрової кукурудзи обмежує специфічна дія гену $\mathrm{su}_{1}$. Вивчення нових зразків за висотою рослин виявила, що лінія РКЦ 410-3, у якої даний показник знаходився на рівні 110 см, відносяться до низькорослих (3\%). Максимальну кількість ліній $72 \%$ віднесено до групи середньорослих (140-160 см). До високорослих (понад 165 см) віднесено $25 \%$ ліній, серед них КЦ 42-3, КЦ 604-1, КЦ 502-1, РКЦ 310-1.

Кращими за висотою прикріплення качанів на стеблі виявились лінії КЦ 207-1, КЦ 208-3, КЦ 209-2, РКЦ 36, КЦ 42-3, у яких качан формувався на висоті 50-85 см. Майже всі лінії мають добре розвинену мітелку проміжного типу з 10-25 галузками та добру пилкоутворюючу здатність.

Лінії вирізняються низькою кущистістю. Кількість качанів на рослині варіювала в межах 0,8-2 шт. Виділено 2 лінії (КЦ 346-2-1, РКЦ 28-2), у котрих кількість качанів стабільно по роках вивчення знаходилась на рівні 1,8-2 шт.

Одним із найважливіших показників придат- ності ліній для використання в селекційних програмах зі створення гібридів $є$ продуктивність рослини.

Ця ознака має складну організацію і обумовлена генотипом, але в значній мірі також залежить від умов вирощування. За цим показником стандарт КС 209а (76,5 г зерна з рослини) на 1024 \% перевищили КЦ 207-1, РКЦ 36, КЦ 42-3, РКЦ 310-1.

Аналіз елементів структури індивідуальної продуктивності виявив такі лінії з масою качана 90-120 г: КЦ 207-1, КЦ 504-2-2, КЦ 602-2, РКЦ 28-2, РКЦ 36, РКЦ 910, КЦ 11, КЦ 27-5. До групи з масою качана 70-90 г віднесено 9 ліній, що $\epsilon$ достатнім рівнем для цукрової кукурудзи. Решта зразків мала низьку та дуже низьку масу качана.

Розподіл ліній по довжині качанів установив, що у $61,2 \%$ зразків качани були середні за розміром (10-15 см), 38,8 \% довгокачанних (15-18 см). Найбільш цінними $є$ останні, до яких, зокрема, належать КЦ 27,5, РКЦ 36, РКЦ 28-2, КЦ 602-2 та інші.

Для цукрової кукурудзи важливою ознакою $\epsilon$ товщина качана, адже зразки з товстим качаном мають підвищену здатність утримувати вологу i більш ефективно використовувати їі для формування зерна, що забезпечує посухостійкість таких форм.

До групи 3 діаметром качана 4,1-5 см віднесено 11 ліній, зокрема РКЦ 910, РКЦ 36, КЦ 504-2-2, КЦ 207-1. Решта 64,6 \% ліній віднесено до групи 3 середнім діаметром качана $(3,1-4$ см).

За ознакою кількість рядів зерен на качані вигідно вирізнялись лінії КЦ 11, РКЦ 36, КЦ 604, котрі мали 17-18 рядів. 
2. Лінії-джерела господарськи цінних ознак цукрової кукурудзи, 2010-2012 рр.

\begin{tabular}{|c|c|c|c|c|c|c|c|c|c|c|c|}
\hline \multirow{2}{*}{ Лінія } & \multicolumn{3}{|c|}{$\begin{array}{c}\text { Зернова } \\
\text { продуктивність, г }\end{array}$} & \multirow{2}{*}{ 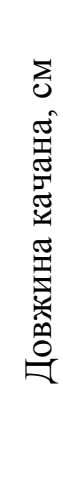 } & \multirow{2}{*}{ 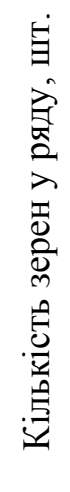 } & \multirow{2}{*}{ 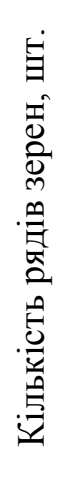 } & \multirow{2}{*}{ 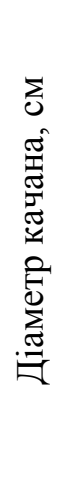 } & \multirow{2}{*}{ 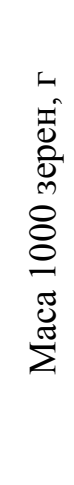 } & \multicolumn{2}{|c|}{ Висота, см } & \multirow{2}{*}{ 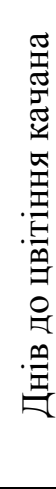 } \\
\hline & $\mathrm{X}$ & V & $\mathrm{S}$ & & & & & & рослини & $\begin{array}{c}\text { прикріплення } \\
\text { верхнього } \\
\text { качана }\end{array}$ & \\
\hline РКЦ 36 & 107,4 & 6,9 & 7,50 & 16 & 34 & 18 & 4,7 & 205 & 180 & 60 & 56 \\
\hline РКЦ 310-1 & 95 & 11,1 & 10,5 & 15 & 16 & 27 & 4,2 & 270 & 175 & 50 & 55 \\
\hline КЦ 207-1 & 94 & 12,8 & 12,0 & 15 & 17 & 30 & 4,5 & 280 & 180 & 68 & 59 \\
\hline КЦ 11 & 90 & 11,7 & 10,6 & 13 & 18 & 33 & 3,9 & 220 & 166 & 49 & 56 \\
\hline КЦ 27-5 & 88,8 & 34 & 30,1 & 16 & 17 & 36 & 4,2 & 220 & 170 & 39 & 56 \\
\hline КЦ 906-1 & 88,7 & 14,5 & 17,5 & 14 & 16 & 28 & 4,5 & 219 & 150 & 30 & 53 \\
\hline КЦ 42-3 & 88,2 & 18,4 & 16,2 & 16 & 16 & 26 & 4,2 & 250 & 190 & 91 & 66 \\
\hline КЦ 504-2-2 & 84,7 & 10,6 & 8,9 & 14 & 12 & 27 & 4,3 & 280 & 160 & 31 & 50 \\
\hline
\end{tabular}

$\mathrm{X}$ - середнє за три роки, $\mathrm{V}$ - коефіцієнт варіації, $\mathrm{S}$ - середньоквадратичне відхилення.

Ознака «кількість зерен на качані» є однією 3 основних, адже вона забезпечує індивідуальну продуктивність рослини.

Дуже високою озерненістю качана (понад 500 шт.) характеризувались лише 4 лінії: РКЦ 36, РКЦ 12-1, КЦ 11, КЦ 27, що становить $12 \%$ від загальної кількості. Значна кількість оцінених зразків $28,4 \%$ мала відносно високу озерненість качана (400-500 шт.).

Важливим елементом у структурі продуктивності є маса 1000 зерен. Виділено 23 лінії з масою 1000 зерен понад 200 г.

Кращі з них: КЦ 207-1, КЦ 504-2-2, КЦ 804-3, КЦ 208-3, КЦ 807-5, КЦ 602-2, КЦ 901-1, РКЦ 28-2, КЦ 11, КЦ 42-3. Відмічено, що лінії КЦ 807-5, КЦ 602-2, РКЦ 910, РКЦ 28-2, РКЦ 70, КЦ 11, ВН 1, КЦ 804-3 забезпечували високу конкурентоздатність генотипів за рахунок підвищення маси 1000 зерен у найбільш сприятливих умовах вирощування.

В селекційній роботі особливо ціняться зразки, в котрих в одному генотипі поєднані декілька цінних ознак. Серед ліній, що вивчалися, комплексом ознак володіють:

- РКЦ 36, КЦ 207-1, КЦ 42-3 - висока зернова продуктивність, висока озерненість качана, дов- гокачанність, крупнокачанність, багаторядність, високорослість, високе прикріплення качанів, стійкість до вилягання;

- РКЦ 28-2 - відносно висока зернова продуктивність, довгокачанність, багатокачанність, високий вміст білка;

- КЦ 27-5, КЦ 11 - висока кількість зерен на качані та середня маса 1000 зерен;

- ВН 1, КЦ 502-1 - ранньостиглість, багатокачанність.

Характеристика кращих з них наведено в таблиці 2.

Висновок. Основний напрям селекції цукрової кукурудзи - створення міжлінійних гібридів, котрі формують високий урожай, придатні до механізованого збору качанів, стійкі до основних хвороб та шкідників, а також мають високі технологічні якості зерна.

Ефективне вирішення даних завдань неможливе без знання морфологічних та біологічних особливостей самозапилених ліній.

Виділені в результаті вивчення лінії з високим рівнем ознак та їх комплексом можуть з успіхом застосовуватися для створення нових конкурентоздатних, високотехнологічних гібридів цукрової кукурудзи. 


\section{БІБЛІОГРАФІЯ}

1. Доспехов Б. А. Методика полевого опыта / Б. А. Доспехов. - М. : Агропромиздат, 1985. - 351 с.

2. Цукрова кукурудза - багате джерело мікроелементів та вітамінів / [Загинайло М. І., Лівандовський А. А., Таганцова М. М., Гаврилюк В. М.] // Науково-виробничий журнал «Насінництво». №5 (137). - К., 2014. - С. 11.

3. Класифікатор-довідник виду Zea mays L. / [підг. Гур'єва I. А., Рябчун В. К. та ін.]. - Х., 1994. - 73 c.

4. Клімова О. Є. Науково-практичні засади селекційного поліпшення цукрової кукурудзи / О. Є. Клімова // Посібник українського хлібороба. - 2015. - №1. - С. 100-107.

5. Клімова O. $C$. Збагачення потенціалу генетичного ресурсу цукрової кукурудзи / О. Є. Клімова // Генетичні ресурси рослин. - Х., 2010. №8. - C. 134-142.

6. Методичні рекомендації польового та лабораторного вивчення генетичних ресурсів кукурудзи / [підг. Гур'єва I. А., Рябчун В. К. та ін.]. Х., 1995. - $29 \mathrm{c}$.

7. Чирков Ю. И. Основы агрометеорологии / Ю. И. Чирков. - Ленинград : Гидрометиздат, 1988. - 244 c.
8. Тимчук С. М. Селекція гібридів кукурудзи харчового та технічного призначення / С. М. Тимчук : матеріали міжнар. конф., присвяченої 90річчю від заснування Інституту рослинництва ім. В. Я. Юр'єва [«Наукові основи стабілізації виробництва продукції рослинництва»]. - Х., 2001. C. $171-181$.

9. Giroux M. J. ADP-glucose pyrophosphorylase in shrunken 2 and brittle 2 mutants of maize / M. J. Giroux, L. C. Hannah // Mol. Gen. Genet. 1994. - V. 243. - P. 400-408.

10. Has $V$. Genetic inheritance of some important characters of sweet corn / V. Has, I. Has // Not. Bot. Agrobot. Cluj. - 2009. - V. 37. - P. 244-248.

11. Nelson O.E. Starch synthesis in maize endosperm / O. E. Nelson, D. Pan // Ann. Rev. Plant Physiol. Plant Mol. Biol. - 1995. - V. 46. - P. 475496.

12. Collection of maize endosperm structure mutante: working out evaluation and utilization in breeding / [Tymchuk V. M., Ryabchun V. K., Boguslavsky R. L. et all] : materials of Int. Conf. Genetic collections, isogenic and alloplastic lines. Novosibirsk. 